\title{
Synthesis of Gallium Oxide Hydroxide Crystals in Aqueous Solutions with or without Urea and Their Calcination Behavior
}

\author{
A. Cüneyt Taş, ${ }^{* \dagger}$ Peter J. Majewski, and Fritz Aldinger ${ }^{*}$ \\ Max-Planck-Institut fuer Metallforschung, Pulvermetallurgisches Laboratorium, Stuttgart D-70569, Germany
}

\begin{abstract}
Gallium oxide hydroxide $\left(\mathrm{GaOOH} \cdot x \mathrm{H}_{2} \mathrm{O}\right)$ single crystals were synthesized in aqueous solutions by using two different precipitation techniques: homogeneous decomposition of urea and forced hydrolysis in pure water. Precipitation of crystals started at exactly the same $\mathrm{pH}$ value (i.e., 2.05 at $85^{\circ} \mathrm{C}$ ) in both cases. The morphology of crystals turned out to be quite different (zeppelin-like with urea, rodlike without urea) in each of the above methods. Calcination of these gallium oxide hydroxide crystals in air at temperatures $\geq 500^{\circ} \mathrm{C}$ transformed them into $\mathrm{Ga}_{2} \mathrm{O}_{3}$. Characterization of the samples was performed by $\mathrm{X}$-ray diffractometry, scanning electron microscopy, thermogravimetry/differential thermal analysis, Fourier transform infrared spectroscopy, and ICP, carbon, and nitrogen analyses.
\end{abstract}

\section{Introduction}

$\mathrm{G}$ ALLIUM (named after the region Gallia of France ${ }^{1}$ ) is an Jelement, which is more abundant in the earth's crust than some of the technologically important elements, such as $\mathrm{B}, \mathrm{Pb}, \mathrm{Bi}$, $\mathrm{Nb}, \mathrm{Mo}, \mathrm{W}, \mathrm{Hg}$, or $\mathrm{Sn}^{2}{ }^{2}$ Gallium oxide, like other oxides of group III metals, is widely used for the preparation of phosphors and catalysts. $\mathrm{Ga}_{2} \mathrm{O}_{3}$ is normally an insulator, with a forbidden energy gap of $\sim 4.9 \mathrm{eV} .^{3}$ However, calcination of $\mathrm{Ga}_{2} \mathrm{O}_{3}$ in reducing atmospheres turns it into an n-type semiconductor, due to the creation of oxygen vacancies. ${ }^{4}$

The high-temperature structure ${ }^{4,5}$ of $\mathrm{Ga}_{2} \mathrm{O}_{3}$ ( $\beta$ form) is monoclinic (space group $C 2 / \mathrm{m}$ ), with the lattice parameters $a=12.214$, $b=3.037, c=5.798 \AA, \beta=103.83^{\circ} .6{ }^{6} \beta-\mathrm{Ga}_{2} \mathrm{O}_{3}$ is only one of five well-known forms ${ }^{7-9}$ of gallium oxide: $\alpha^{-}, \chi^{-}, \delta-$, and $\varepsilon-\mathrm{Ga}_{2} \mathrm{O}_{3}$, and all of these polymorphs are converted to $\beta-\mathrm{Ga}_{2} \mathrm{O}_{3}$ at $T>870^{\circ} \mathrm{C} .{ }^{10}$ Growth of the single crystals ${ }^{11}$ of $\beta-\mathrm{Ga}_{2} \mathrm{O}_{3}$ has been studied by Okada et al., ${ }^{12}$ using the tin-flux method, and $\mathrm{Ga}_{2} \mathrm{O}_{3}$ nanowires were prepared by Zhang et al. ${ }^{13}$ and Choi et al. ${ }^{14}$

Manufacture of n-type semiconducting $\mathrm{Ga}_{2} \mathrm{O}_{3}$ thin films on electrically insulating substrates has been studied by Meixner et $a l .,{ }^{15}$ which are considered and developed for the detection of reducing gases. It was also reported that different gas sensitivities can be tailored by the appropriate setting of the operating temperature, and at temperatures in excess of $900^{\circ} \mathrm{C}$, the sensors may even be operated as $\mathrm{O}_{2}$ sensors. ${ }^{16-19}$ On the other hand, Haneda et al. reported ${ }^{20,21}$ that the $\mathrm{Ga}_{2} \mathrm{O}_{3}-\mathrm{Al}_{2} \mathrm{O}_{3}$ ceramic catalysts prepared by using the sol-gel method showed superior activity (as compared with those of either pure $\mathrm{Al}_{2} \mathrm{O}_{3}$ or $\mathrm{Ga}_{2} \mathrm{O}_{3}$ ) for the selective reduction of $\mathrm{NO}$ with propene in the presence of $\mathrm{H}_{2} \mathrm{O}$ and $\mathrm{SO}_{2}$. It should be noted here that during the preparation of ceramics, Haneda et al. ${ }^{20,21}$ mentioned that the pure $\mathrm{Ga}_{2} \mathrm{O}_{3}$ catalysts of their

N. J. Dudney—contributing editor

\footnotetext{
Manuscript No. 188296. Received August 28, 2000; approved January 31, 2002. ${ }^{\star}$ Member, American Ceramic Society.

Present address: Merck Biomaterial GmbH, F129/218, Darmstadt D-64271, Germany.
}

study were prepared "from gallium hydroxide obtained by adding urea to an aqueous solution of gallium(III) nitrate and stirring at $90^{\circ} \mathrm{C}$ for $10 \mathrm{~h}$, followed by calcination of the recovered precipitates at $600^{\circ} \mathrm{C}$ for $5 \mathrm{~h}$ in an air atmosphere."

$\mathrm{Ga}_{2} \mathrm{O}_{3}$ has recently been used in the synthesis of solid electrolytes of superior (as compared with $\mathrm{Y}$-stabilized zirconia) ionic conductivity, i.e., $\mathrm{La}_{0.8} \mathrm{Sr}_{0.2} \mathrm{Ga}_{0.8} \mathrm{Mg}_{0.2} \mathrm{O}_{2.8}$ (LSGM), ${ }^{22,23}$ also beyond its significance for the semiconductor, optoelectronic, and catalysis technologies. We have encountered the incidental formation of gallium oxide hydroxide $(\mathrm{GaO}(\mathrm{OH}))$ in aqueous solutions throughout the course of our recent studies, which were mainly focused on the wet-chemical synthesis of powders of doped $\mathrm{LaGaO}_{3}$ fuel cell ceramics. ${ }^{24,25}$

The first experimental study on the transformation of gallium oxide polymorphs and hydroxides was performed by Laubengayer et $a .^{7}$ in 1939 over the temperature range of $110^{\circ}$ to $1000^{\circ} \mathrm{C}$. These authors synthesized $\alpha-\mathrm{GaO}(\mathrm{OH})$ from a gel obtained through the hydrolysis of gallium nitrate or gallium chloride, after calcination at temperatures between $110^{\circ}$ and $300^{\circ} \mathrm{C}$. It was claimed $^{7}$ that, in this temperature range, $\mathrm{Ga}(\mathrm{OH})_{3}$ transforms in a sluggish manner to $\alpha-\mathrm{GaO}(\mathrm{OH})$ in aqueous solution. Roy et al. ${ }^{8}$ also confirmed that the $\mathrm{Ga}(\mathrm{OH})_{3}$ precipitates, which are likely to be metastable compared with gallium oxide hydroxide, would only be converted into $\alpha-\mathrm{GaO}(\mathrm{OH})$ with time at ambient temperature. However, the transformation of $\alpha-\mathrm{GaO}(\mathrm{OH})$ to $\beta-\mathrm{Ga}_{2} \mathrm{O}_{3}$ was observed by Laubengayer et $a l^{7}$ at temperatures higher than $300^{\circ} \mathrm{C}$.

Precipitation of $\mathrm{GaO}(\mathrm{OH})$ in solutions containing dissolved gallium chloride, on the addition of various alkalis (such as $\mathrm{NaOH}$, $\mathrm{KOH}, \mathrm{NH}_{4} \mathrm{OH}, \mathrm{NaHCO}_{3}$, and $\mathrm{Na}_{2} \mathrm{CO}_{3}$ ), has been studied by Sato et $a .^{26}$ These authors reported that the freshly precipitated (at $\mathrm{pH}$ values varying between 6 and 10) precursors were all X-ray amorphous $^{26}$ and converted to crystalline $\alpha-\mathrm{GaO}(\mathrm{OH})$, with an orthorhombic crystal structure similar to that of diaspore $(\alpha-$ $\mathrm{AlO}(\mathrm{OH})),{ }^{27,28}$ only after about 1 day of aging in their basic mother liquors. Pokrovski et al. ${ }^{29}$ determined the thermodynamic properties of $\alpha-\mathrm{GaO}(\mathrm{OH})$, at temperatures up to $700 \mathrm{~K}$, by using low-temperature heat capacity and solubility tests, and their data confirmed that gallium oxide hydroxide was the stable phase in the $\mathrm{Ga}-\mathrm{O}-\mathrm{H}$ system up to $300^{\circ} \mathrm{C}$. It should be noted that $\alpha-\mathrm{GaO}(\mathrm{OH})$ is also a structural analogue of a group of previously studied oxidic hydrates, such as $\alpha-\mathrm{ScO}(\mathrm{OH}),{ }^{30}$ groutite $(\alpha-\mathrm{MnO}(\mathrm{OH})),{ }^{31}$ and goethite $(\alpha-\mathrm{FeO}(\mathrm{OH})){ }^{32-35}$

Avivi et al. $^{36}$ produced so-called rolled-up tubular particles of $\alpha-\mathrm{GaO}(\mathrm{OH})$ after exposing a $0.114 M$ aqueous solution of $\mathrm{GaCl}_{3}$ to ultrasonic irradiation for $6 \mathrm{~h}$, by inserting the titanium horn of an ultrasonic finger into this solution. The same authors repeated the above procedure for $\mathrm{InCl}_{3}$ solutions $(0.68 M)$, but this time ${ }^{37}$ to form rodlike $\mathrm{In}(\mathrm{OH})_{3}$ particles. The researchers concluded in both of these studies ${ }^{36,37}$ that the sonochemical reaction provided by the inserted tip of the ultrasonic finger led to the sonohydrolyses of the gallium chloride or indium chloride solutions.

Matijevic et al. ${ }^{38}$ prepared uniform colloidal indium hydroxide (i.e., $\mathrm{In}(\mathrm{OH})_{3}$ ) particles by using either the technique of "homogeneous precipitation with urea" ${ }^{39-50}$ or forced hydrolysis of aqueous solutions at elevated temperatures in the absence of any additives. The authors have systematically varied the indium salt 
concentration, the addition of sodium sulfate and urea, the solution $\mathrm{pH}$, the temperature, and the aging time to see the effect of these parameters on the composition, size, and shape of the resulting particles. Matijevic et $a l^{51}$ have also studied the preparation of $\mathrm{In}(\mathrm{OH})_{3}$ particles by peptization of precipitates obtained in $\mathrm{NaOH}-$ $\mathrm{InCl}_{3}$ solutions of varying concentrations.

In this paper, we used the precipitation methods of (a) the homogeneous decomposition of urea, ${ }^{39-50,52-54}$ and (b) forced hydrolysis (without urea, at $\left.90^{\circ} \mathrm{C}\right)^{38}$ of gallium nitrate solutions to form the $\mathrm{GaO}(\mathrm{OH})$ crystals. The product powders are fully characterized (as identified via, for example, phases present, precipitate morphology, infrared (IR) behavior, and thermogravimetric and chemical analyses).

\section{Experimental Procedure}

$\mathrm{Ga}\left(\mathrm{NO}_{3}\right)_{3} \cdot 0.4 \mathrm{H}_{2} \mathrm{O} \quad(99.999 \%$ pure, Sigma-Aldrich Chemie $\mathrm{GmbH}$, Steinheim, Germany) was used as the only gallium source throughout this study. A $0.3704 M\left(\mathrm{Ga}^{3+}\right)$ stock solution was first prepared by dissolving an appropriate amount of gallium nitrate in deionized water. Urea used was also reagent-grade $(>99 \%$ pure, Merck, Darmstadt, Germany). Synthesis experiments were performed by two different precipitation techniques.

(a) Homogeneous Decomposition of Urea: A $6.7 \mathrm{~mL}$ aliquot (i.e., $0.0025 \mathrm{~mol}$ of $\mathrm{Ga}^{3+}$ ) of the gallium nitrate stock solution was placed into a $150 \mathrm{~mL}$ capacity glass beaker, followed by the addition of $90 \mathrm{~mL}$ of deionized water. The solution was mixed at room temperature for $15 \mathrm{~min}$, and $1.756 \mathrm{~g}$ of urea (i.e., 0.0292 mol) was then dissolved in it. The resultant clear solution was again mixed at room temperature for another $15 \mathrm{~min}$, followed by heating on a hot plate to $90^{\circ} \mathrm{C}$ in about $45 \mathrm{~min}$. The beaker was tightly covered with Parafilm ${ }^{\circledR}$, before heating, to avoid excessive evaporation. The solution was finally aged at a constant temperature of $90( \pm 1)^{\circ} \mathrm{C}$ for $95 \mathrm{~min}$. The molar ratio of urea to $\mathrm{Ga}^{3+}$ was kept constant at a value of 11.68 throughout this study. The above procedure was also repeated by placing the same solution (containing urea) into a $100 \mathrm{~mL}$ capacity screw-capped glass bottle at room temperature, followed by inserting it into a microprocessorcontrolled oven for heating and aging (95 min), which was preheated to $90^{\circ} \mathrm{C}$, to produce the same powders.

(b) Forced Hydrolysis: A $6.7 \mathrm{~mL}$ aliquot (i.e., $0.0025 \mathrm{~mol}$ of $\mathrm{Ga}^{3+}$ ) of the gallium nitrate stock solution was placed into a 150 $\mathrm{mL}$ capacity glass beaker, followed by the addition of $90 \mathrm{~mL}$ of deionized water. This solution was mixed at room temperature for $15 \mathrm{~min}$, followed by heating on an hot plate to $90^{\circ} \mathrm{C}$ in about 45 min. The beaker was covered with Parafilm ${ }^{\circledR}$ before the start of heating to reduce evaporation, and the solution was aged for 95 min at a constant temperature of $90( \pm 1)^{\circ} \mathrm{C}$. A portion of the same solution was also forced to undergo hydrolysis in a $100 \mathrm{~mL}$ capacity screw-capped glass bottle, placed into an oven at $90^{\circ} \mathrm{C}$, as described previously.

The formed precipitates (in each of the above-described procedures), after $95 \mathrm{~min}$ of aging at a constant temperature of $90^{\circ} \mathrm{C}$, were finally separated from their mother liquors by centrifugal filtration (at $8000 \mathrm{rpm}$ ), followed by washing four times with 2-propanol ( $>99 \%$ pure, Merck). Washed precipitates were dried in an oven at $90^{\circ} \mathrm{C}$, overnight. Dried powders were first finely ground by hand using an agate mortar and pestle, and finally calcined isothermally (as loose powders in clean alumina boats) in a stagnant-air-atmosphere box furnace over a temperature range of $250^{\circ}$ to $1200^{\circ} \mathrm{C}$. Calcined powders were recovered from the $\mathrm{Al}_{2} \mathrm{O}_{3}$ boats by gently tapping them onto a clean piece of paper. Each calcination batch of powders was heated to the specified temperature at a rate of $5^{\circ} \mathrm{C} / \mathrm{min}$, annealed at this temperature for $6 \mathrm{~h}$, and then furnace-cooled to room temperature.

The phase constitution of the powders was analyzed, as a function of temperature (on isothermally calcined samples), using a powder X-ray diffractometer (Model D-5000, Siemens GmbH, Karlsruhe, Germany) with monochromated $\mathrm{CuK} \alpha_{1}$ radiation (40 $\mathrm{kV}, 30 \mathrm{~mA}$ ). For determination of the lattice parameters, a scan rate of $0.9^{\circ} 2 \theta / \mathrm{min}$ (over the range of $10-80^{\circ} 2 \theta$ ) was used; a silicon external standard, along with the Appleman Least Squares Refinement Program, ${ }^{55}$ was used to correct for systematic errors.

The pyrolysis of accurately weighed $224.8-\mathrm{mg}$ portions of ground powders was monitored via simultaneous thermogravimetric and differential thermal analysis (TG/DTA) (Model STA501, Bähr GmbH, Bremen, Germany) in an air atmosphere at a heating rate of $5^{\circ} \mathrm{C} / \mathrm{min}$ up to $1040^{\circ} \mathrm{C}$. Fourier transform infrared (FTIR) spectroscopy analyses of the samples were performed (Model IFS 66 , Bruker $\mathrm{GmbH}$, Karlsruhe, Germany) after they were mixed (1 wt\%) with dry $\mathrm{KBr}$ to form pellets that were used in these analyses. The residual carbon and nitrogen contents of the uncalcined and calcined powders were determined using a combustion-IR absorption method (Model CS-800, Eltra GmbH, Neuss, Germany). ICP-AES analyses were performed to test the contamination of $\mathrm{GaO}(\mathrm{OH})$ or $\mathrm{Ga}_{2} \mathrm{O}_{3}$ powders by aluminum, after calcination of the samples in alumina boats at elevated temperatures (Model JY-70Plus, Jobin Yvon S.A., Longjumenau, France). The powder morphologies were monitored using both fieldemission scanning electron microscopy (FESEM) (Model DSM 982-Gemini, Zeiss GmbH, Oberkochen, Germany) and scanning electron microscopy (SEM) (Model Stereoscan-200, Cambridge Instruments, Ltd., Cambridge, U.K.).

\section{Results and Discussion}

\section{(1) Homogeneous Decomposition of Urea}

It is known ${ }^{39-50,52-54}$ that the formation of a solid precursor in aqueous precipitation experiments, which relies on the homogeneous decomposition of urea, is governed by the controlled generation of hydroxide and carbonate ions. The kinetics of the decomposition of urea in water appears to depend on the urea concentration, as well as other important variables, such as temperature and the presence and concentration of cations. The present study, however, excludes the effects of the abovementioned variables on precipitate morphology and composition, since the molar ratio of urea to $\mathrm{Ga}^{3+}$, as well as the solution temperature, has not been varied.

The decomposition of urea and the progress of gallium oxide hydroxide precipitation was followed as a function of aging time and $\mathrm{pH}$, and a typical plot of $\mathrm{pH}$ versus reaction time is given in Fig. 1. The trace of $\mathrm{pH}$ variation with time for $0.026 M \mathrm{Ga}^{3+}$ solutions (labeled "w/o urea," i.e., the "forced hydrolysis" experiments) is also included in Fig. 1 for the purpose of direct comparison. The solution temperature has been raised from $23^{\circ}$ to $90^{\circ} \mathrm{C}$ in about $45 \mathrm{~min}$, and the insert in Fig. 1 displays the typical variation of temperature with time in both kinds of gallium oxide hydroxide precipitation experiments.

It is interesting to note that precipitation started (observed by the onset of a slight turbidity in the solutions) when the temperature reached $85^{\circ} \mathrm{C}$, regardless of the presence of urea in the solutions. The initial $\mathrm{pH}$ value of the $0.026 \mathrm{M} \mathrm{Ga}^{3+}$ solutions (with or without urea) was in the range of 2.75 to 2.80 at $23^{\circ} \mathrm{C}$, and the precipitation started in both kinds of solutions when the $\mathrm{pH}$ dropped down exactly to 2.05 . This means that urea had no effect at all in "starting" the precipitation in gallium nitrate solutions of this study. On the other hand, the rise in $\mathrm{pH}$ (when $t>80 \mathrm{~min}$ ) observed in urea-containing gallium nitrate solutions, as seen in Fig. 1, is characteristic of the decomposition of urea, and it corresponds to the start of dissociation of $\mathrm{NH}_{4} \mathrm{OH}$ (which is an initial byproduct of urea decomposition together with $\mathrm{H}_{2} \mathrm{CO}_{3}$ ) into $\mathrm{NH}^{4+}$ and $\mathrm{OH}^{-}$. The detailed sequence of chemical reactions describing the decomposition of urea in aqueous media has previously been documented. ${ }^{47,56}$

The extremely small amounts of precipitates formed just at the precipitation-start point (i.e., $\mathrm{pH} 2.05, T=85^{\circ} \mathrm{C}$ ) have been immediately recovered from the urea-containing solutions by quenching the beaker of that solution in an ice-water bath $\left(0^{\circ} \mathrm{C}\right)$, followed by centrifugal filtration at $10000 \mathrm{rpm}$, and 2-propanol washing $(5 \times)$ and drying at $90^{\circ} \mathrm{C}$. The unique morphologies of these precipitates are depicted by the FESEM micrographs given in Figs. 2(a) and (b). These little (200 to $500 \mathrm{~nm}$ long) "zeppelins" 


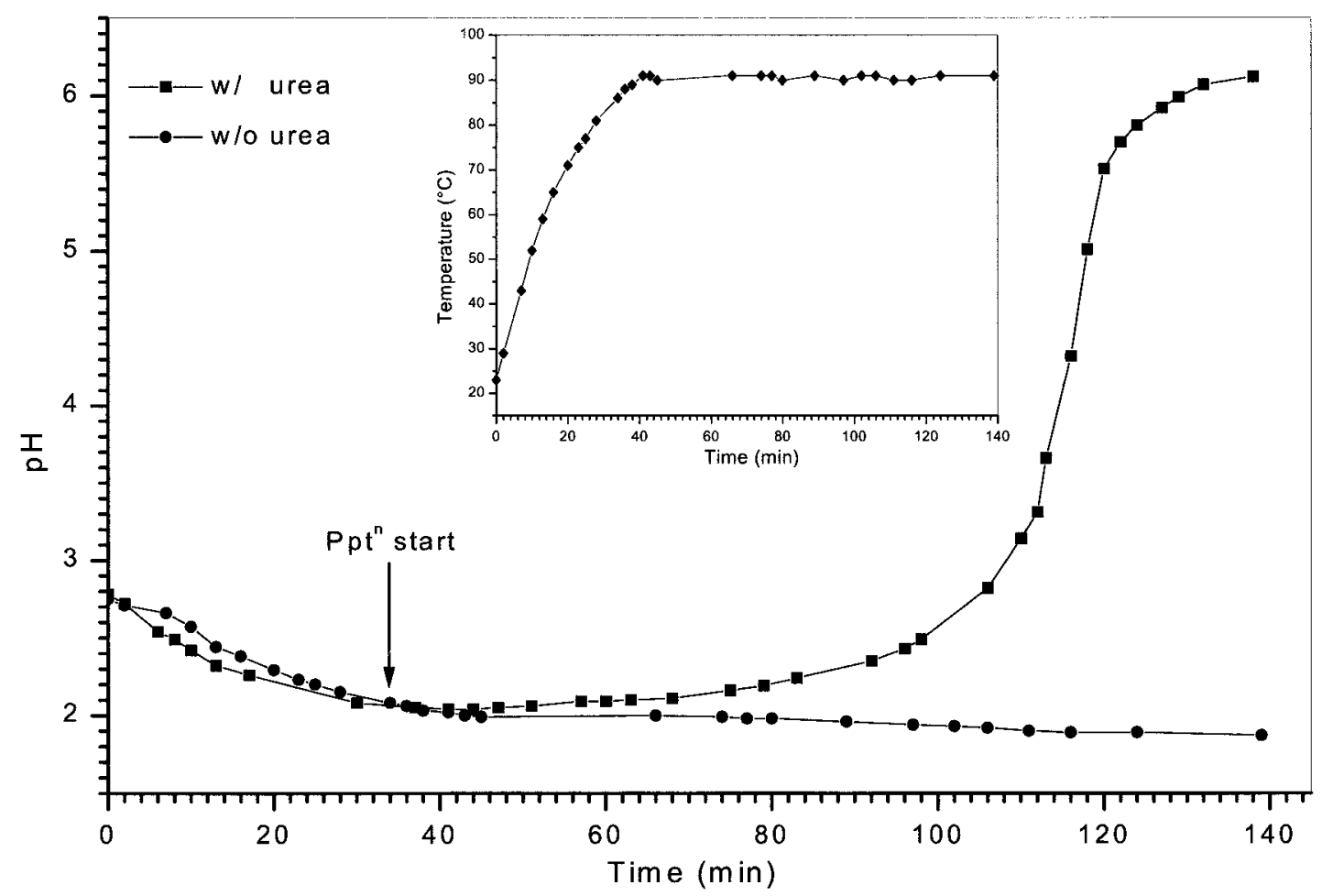

Fig. 1. Plot of $\mathrm{pH}$ versus aging time in the precipitation solutions. (Insert shows the temperature-time variation during the synthesis.)

of $\alpha-\mathrm{GaO}(\mathrm{OH})$ were found to be crystalline with an orthorhombic unit cell $(a=4.5606(3), b=9.7975(4), c=2.9731(2) \AA$, and $V=$ $132.85 \AA^{3}$ ). The granular surface texture of the zeppelins is thought to be due to the local dehydration under long electronbeam exposure. ${ }^{53}$ The zeppelins also had a pronounced elongation in the (001) crystallographic direction. On the other hand, the precipitates recovered from the same solution (with urea) after 95 min of aging (at $90 \pm 1^{\circ} \mathrm{C}, \mathrm{pH}$ 6.10) in the mother liquor still had the zeppelin morphology (see the SEM micrograph of Fig. 2(c)), but their lengths were found to increase to about 1 to $2 \mu \mathrm{m}$. The bigger zeppelins had also the same orthorhombic unit cell as given above.

Figure 2(d), on the other hand, shows the morphology of $\alpha-\mathrm{GaO}(\mathrm{OH})$ precipitates collected from their mother liquors following $24 \mathrm{~h}$ of aging at $90^{\circ} \mathrm{C}(\mathrm{pH} 7.8)$. The zeppelin morphology disappeared by a mechanism of dissolution-precipitation and the spherical particles formed were found to have an average particle size of $50-60 \mathrm{~nm}$. A similar dissolution-precipitation process was previously observed by Ramanathan et al. ${ }^{57}$ in the precipitation of crystalline boehmite $(\mathrm{AlO}(\mathrm{OH}))$ during the aluminum nitrate-urea reactions taking place at around $100^{\circ} \mathrm{C}$ for prolonged aging times.

This unique morphology (zeppelins or ellipsoidal acicular particles) observed by us this time for gallium oxyhydroxide crystals, which were only grown out of urea-containing solutions, has also been encountered by several other previous researchers $^{35,52,53,58-60}$ working on the aqueous synthesis of $\alpha-\mathrm{FeOOH}$ (i.e., goethite) in the presence of urea. These researchers concluded that the morphology of goethite crystals was chiefly a function of the $\mathrm{pH}$ of the system ${ }^{61}$ and showed morphologic variations along the $\mathrm{pH}$ scale. However, it is quite interesting to mention here that a similar ellipsoidal particle morphology was detected by $\mathrm{Lu}$ et $a l .{ }^{62}$ during the hydrothermal synthesis of zinc hydroxide powders from zinc nitrate solutions titrated with $\mathrm{NH}_{4} \mathrm{OH}$.

\section{(2) Forced Hydrolysis}

Gallium oxide hydroxide precipitates formed in aqueous solutions (without urea), on the other hand, were only recovered from their mother liquors at the end of $95 \mathrm{~min}$ of aging at $90 \pm 1^{\circ} \mathrm{C}$ and at the final $\mathrm{pH}$ value of 1.87 , and they possessed a unique rodlike morphology as shown in the SEM micrograph of Fig. 3(a), with an average rod length of about $3 \mu \mathrm{m}$. These rods were also crystalline. Formation of rodlike $\mathrm{GaO}(\mathrm{OH})$ is considered to proceed according to the following reaction:

$$
\mathrm{Ga}^{3+}+2 \mathrm{H}_{2} \mathrm{O} \rightarrow \mathrm{GaOOH}+3 \mathrm{H}^{+}
$$

and the solution $\mathrm{pH}$ is slightly decreased with aging (Fig. 1).

A tentative XRD pattern (which is of better crystallographic quality than that of ICDD PDF 06-180 assigned to $\alpha-\mathrm{GaOOH}$ ) has been created for these crystals and is given in Table I. The lattice parameters of these orthorhombic crystals were determined to be $a=4.5545(2), b=9.8007(4), c=2.9738(1) \AA, Z=4$, and $V=$ $132.74 \AA^{3}$. The powder XRD data for these precipitates (without urea) are given by the bottom trace (labeled $90^{\circ} \mathrm{C}$ ) of Fig. 4 . On the other hand, the little and big zeppelins formed in the ureacontaining precipitation solutions also had the same XRD trace, with the same relative intensity values. The crystal structure presented by both kinds of gallium oxide hydroxide crystals was found to be analogous to the structure of diaspore, i.e., $\alpha-\mathrm{AlOOH},{ }^{27,28}$ and the space group of the diaspore structure is regarded to be Pbnm (62). Goethite and groutite (i.e., $\left.\alpha-\mathrm{MnOOH}^{31}\right)$ are also structurally similar to diaspore. However, the $\mathrm{GaO}(\mathrm{OH})$ crystals that we synthesized certainly did not have the Pbnm space group; instead they belonged to either one of the following two space groups: Pma2 (28) or Pmam (51). The reflections for 201, 011, 401, and 601 planes are forbidden for the space group of $\mathrm{Pbnm}$.

It should be noted that gallium nitrate solutions (without urea) are not stable. We observed several times that even the $0.37 M$ stock solutions underwent in situ hydrolysis (by forming tiny white precipitates at the bottom of the glass containers) in about 3 months, while they were just being stored in a fume hood kept at $21 \pm 1^{\circ} \mathrm{C}$. The simple way that we performed the forcedhydrolysis experiments during the course of this study also showed that only heating dilute gallium nitrate solutions resulted easily in the formation of monodispersed $\mathrm{GaO}(\mathrm{OH})$ crystals. 

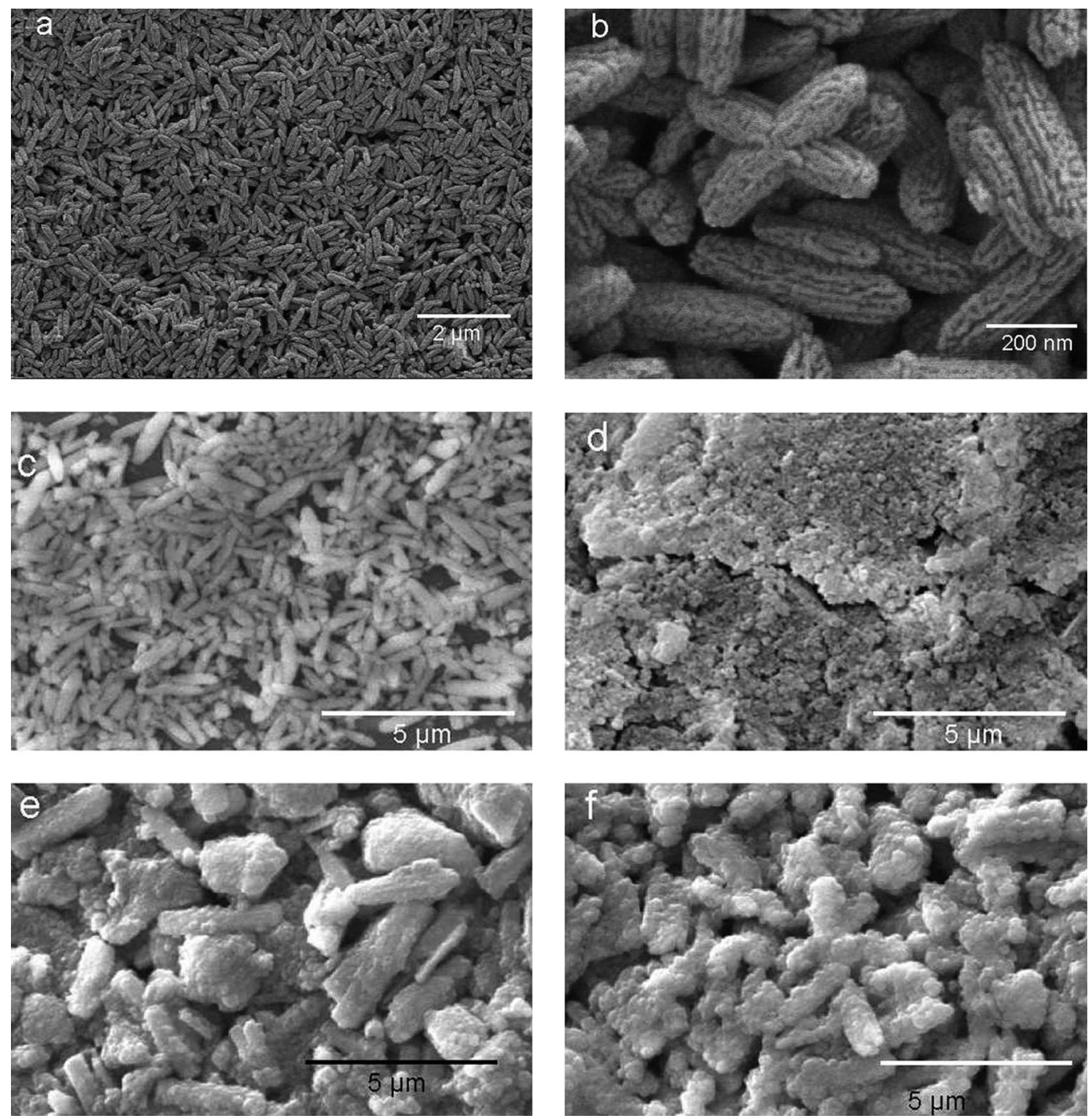

Fig. 2. Electron micrographs of $\mathrm{GaO}(\mathrm{OH})$ crystals synthesized by using urea-containing solutions: (a,b) FESEM micrographs of crystals recovered from the solution immediately after the onset of precipitation, (c) SEM micrograph of crystals recovered from the solution after 95 min of aging following the start of precipitation, (d) SEM micrograph of precipitates recovered from the solution after $24 \mathrm{~h}$ of aging, (e) SEM micrograph of samples calcined at $750^{\circ} \mathrm{C}$, (f) SEM micrograph of crystals calcined at $1000^{\circ} \mathrm{C}$ for $6 \mathrm{~h}$ in air.

The recent work of Avivi et al. ${ }^{36}$ describes the ultrasonification of $\mathrm{GaCl}_{3}$ solutions for $6 \mathrm{~h}$, and mentions the strong necessity of "ultrasonic hydrolysis for the sonochemical formation" of scrolllike cylindrical or tubular gallium oxide hydroxide particles. It should be remembered that the insertion of an ultrasonic finger into a solution, and operating it (at $100 \mathrm{~W} / \mathrm{cm}^{2}$ ) in that solution for a long time like $6 \mathrm{~h}$ would certainly cause a lot of heating of that solution. What these authors actually observed at the end of $6 \mathrm{~h}$ might simply have been the forced hydrolysis of a gallium solution at an elevated temperature, in strong contrast to their sonochemical hypotheses about the nucleation of nanosized particles with a unique rodlike morphology between the interface of the thin liquid layer and the collapsing air bubbles.

\section{(3) Morphology of $\mathrm{GaO}(\mathrm{OH})$ Crystals}

Formation of zeppelin-like (or spindlelike) or rodlike particles under different conditions was reported by previous researchers $^{58-61,63-67}$ in synthesizing $\alpha-\mathrm{FeO}(\mathrm{OH})$, via hydrolysis, from $\mathrm{Fe}\left(\mathrm{NO}_{3}\right)_{3}, \mathrm{FeSO}_{4}$, or $\mathrm{FeCl}_{3}$ solutions. In some of these studies, ${ }^{63-67}$ hydrolysis of the inorganic solutions was typically achieved by the addition of a strong base, such as $\mathrm{NaOH}$. Goni-Elizalde et al.,${ }^{53}$ on the other hand, studied the homogeneous precipitation of $\alpha-\mathrm{FeO}(\mathrm{OH})$ spindles (or zeppelins) in iron(III) sulfate solutions hydrolyzed by urea.
$\alpha-\mathrm{GaO}(\mathrm{OH})$ crystals consist of double chains of edge-shared octahedra, where $\mathrm{Ga}^{3+}$ ions are surrounded by six oxygens and the $c$-axis $(\langle 001\rangle)$ lies parallel to the longitudinal direction of these zeppelins, strongly analogous to the case of $\alpha-\mathrm{FeO}(\mathrm{OH}),{ }^{63}$ while the vertical and horizontal axes are both $\{110\}$. This implies that the preferred growth direction along the width of the zeppelins should be along the $b$-axis $(\langle 010\rangle)$, and the same direction along the thickness should be along the $a$-axis $(\langle 100\rangle)$ of the unit cell. Since each particle is a single crystal, the zeppelin-shaped cross section of the particle has a crystallographic acute angle of about $50^{\circ} . \alpha-\mathrm{FeO}(\mathrm{OH})$ and $\alpha-\mathrm{GaO}(\mathrm{OH})$ have exactly the same diasporelike crystal structure, and for this reason, it is not surprising at all to see the precipitation of same zeppelins or spindles in both cases of oxyhydroxides. ${ }^{64-67}$ The growth of $\alpha-\mathrm{GaO}(\mathrm{OH})$ crystals is being realized by the continuous linking of the $\mathrm{Ga}^{3+} \mathrm{O}_{6}$ chains along the $c$-axis. Kurokawa et al. ${ }^{67}$ reported the transition from rodlike to spindlelike (i.e., zeppelin) morphology in $\alpha-\mathrm{FeO}(\mathrm{OH})$ with the addition of $\mathrm{OH}^{-}$ions (via $\mathrm{NaOH}$ ) into the solution, which supports the findings of the present study. Decomposition of urea (into $\mathrm{NH}_{4} \mathrm{OH}$ and $\mathrm{H}_{2} \mathrm{CO}_{3}$ ) occurs at around $80^{\circ} \mathrm{C}$ and it is followed by dissociation of the reaction products to yield $\mathrm{OH}^{-}$and $\mathrm{CO}_{3}{ }^{2-}$ ions. The gradual but uniform release of $\mathrm{OH}^{-}$ions into the mother liquor results in the nucleation (Figs. 2(a) and (b)) and growth (Fig. 2(c)) of uniformly sized and zeppelin-shaped crystals. Apparently, 

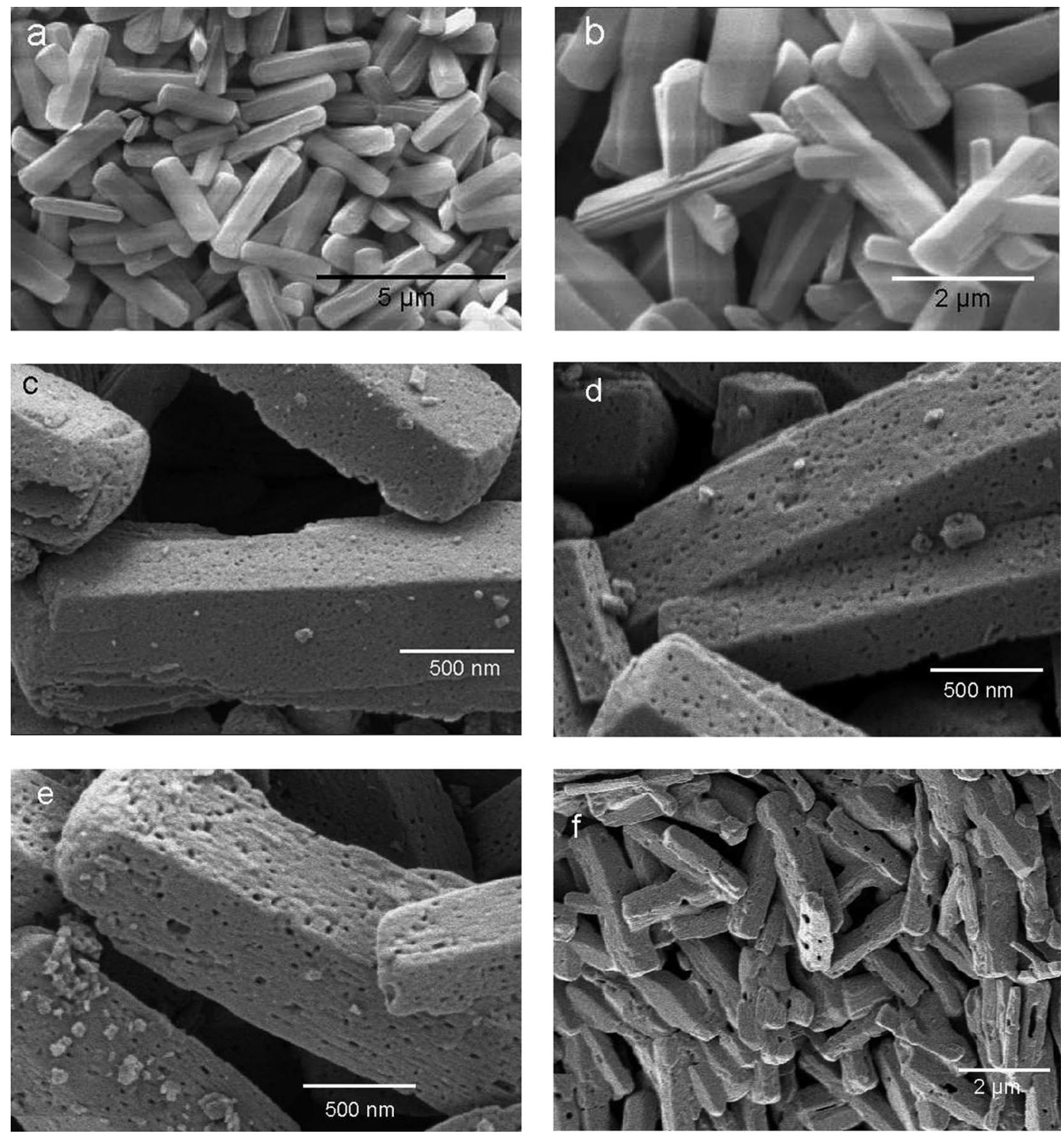

Fig. 3. Electron micrographs of $\mathrm{GaO}(\mathrm{OH})$ crystals synthesized in pure water solutions: (a) SEM micrograph of crystals recovered from the solution after 95 min of aging following the start of precipitation; (b) SEM micrograph of crystals after $250^{\circ} \mathrm{C}$ calcination; (c) FESEM micrograph of crystals after $500^{\circ} \mathrm{C}$ calcination, (d) $750^{\circ} \mathrm{C}$, (e) $1000^{\circ} \mathrm{C}$, and (f) $1200^{\circ} \mathrm{C}$, in air for $6 \mathrm{~h}$.

the $\mathrm{OH}^{-}$ions, supplied by the homogeneous decomposition of urea, allow nucleation and growth to take place also along the 110 and 010 directions of the formed zeppelins. Structural $\mathrm{OH}^{-}$ions found along the faces of the diaspore (or goethite) unit cell might also contribute to the growth of the crystals along their width parallel to the $\langle 010\rangle$ direction. However, in the case of pure water (i.e., in the absence of excess $\mathrm{OH}^{-}$ions) $\alpha-\mathrm{GaO}(\mathrm{OH})$ rodlike crystals are observed to grow only along the longitudinal $c$-axis. The exact role of $\mathrm{CO}_{3}{ }^{2-}$ ions in this mechanism is not yet clear.

\section{(4) Calcination of Gallium Oxide Hydroxide}

The zeppelin morphology of $\mathrm{GaO}(\mathrm{OH})$ crystals, which were initially formed in the presence of urea, drastically changed following calcination for $6 \mathrm{~h}$ in an air atmosphere at $750^{\circ}$ and $1000^{\circ} \mathrm{C}$, as shown in the SEM micrographs of Figs. 2(e) and (f), respectively. The aggregates of fused spheres, which totally replaced the initial $\mathrm{GaO}(\mathrm{OH})$ zeppelins, especially as seen in Fig. 2(f), had average radii of about $150 \mathrm{~nm}$. Calcination at temperatures below $750^{\circ} \mathrm{C}$ (i.e., $250^{\circ}$ and $500^{\circ} \mathrm{C}$ ), on the other hand, did not cause any significant change in the zeppelin morphology. The calcination behavior of $\mathrm{GaO}(\mathrm{OH})$ crystals grown in pure water (without urea) can be followed by the micrographs of Fig. 3. The SEM micrograph given in Fig. 3(b) displays the morphology of gallium oxide hydroxide crystals after calcination at $250^{\circ} \mathrm{C}$ for $6 \mathrm{~h}$. These crystals still had the same $\alpha-\mathrm{GaO}(\mathrm{OH})$ XRD pattern as with those of shown in Fig. 3(a), and had the same morphology, as well. The FESEM micrographs of Figs. 3(c) through (f) show the surface morphology of rodlike crystals after calcination for $6 \mathrm{~h}$ in an air atmosphere at $500^{\circ}, 750^{\circ}, 1000^{\circ}$, and $1200^{\circ} \mathrm{C}$, respectively. The rods preserved their initial shapes (in contrast to zeppelin-like crystals, which formed in urea-containing solutions) at all calcination temperatures, but they became nanoporous on their visible surfaces with increasing calcination temperature. The formation of these nanosized pores is due to the elimination of water from constitutional $\mathrm{OH}$ groups, and this process starts at temperatures above $300^{\circ} \mathrm{C}$. $^{7}$ Finally, as seen from the micrograph of Fig. 3(f), after calcination as a loose powder compact at $1200^{\circ} \mathrm{C}$ for $6 \mathrm{~h}$, the rodlike crystals fused to each other at their mutual point of contact. ICP-AES analysis performed on all of the calcined powders did not show any contamination by $\mathrm{Al}$, which might have arisen by the use of $\mathrm{Al}_{2} \mathrm{O}_{3}$ boats during calcination.

The powder XRD data of precipitated $\mathrm{GaO}(\mathrm{OH})$ crystals, as a function of calcination temperature, is given in Fig. 4. The XRD traces were found to be the same for both kinds (i.e., with urea and without urea) of powders synthesized in this study. $\alpha-\mathrm{GaO}(\mathrm{OH})$ was still the only phase after calcination at $250^{\circ} \mathrm{C}$ for $6 \mathrm{~h}$. Powders 
Table I. Powder XRD Pattern of Gallium Oxide Hydroxide

\begin{tabular}{lccr}
\hline$h k l$ & $d_{\text {calc }}$ & $d_{\text {obs }}$ & $I / I_{0}$ \\
\hline 200 & 4.9005 & 4.9028 & 12 \\
110 & 4.1304 & 4.1321 & 100 \\
210 & 3.3362 & 3.3362 & 12 \\
310 & 2.6547 & 2.6546 & 35 \\
201 & 2.5423 & 2.5425 & 30 \\
011 & 2.4899 & 2.4898 & 6 \\
400 & 2.4502 & 2.4504 & 20 \\
111 & 2.4133 & 2.4136 & 68 \\
211 & 2.2199 & 2.2199 & 10 \\
410 & 2.1578 & 2.1580 & 13 \\
311 & 1.9804 & 1.9805 & 5 \\
401 & 1.8910 & 1.8910 & 5 \\
121 & 1.7780 & 1.7780 & 5 \\
411 & 1.7465 & 1.7463 & 2 \\
221 & 1.6962 & 1.6961 & 18 \\
420 & 1.6681 & 1.6681 & 5 \\
321 & 1.5819 & 1.5819 & 4 \\
511 & 1.5402 & 1.5402 & 15 \\
002 & 1.4869 & 1.4868 & 12 \\
421 & 1.4548 & 1.4548 & 3 \\
601 & 1.4317 & 1.4316 & 7 \\
112 & 1.3990 & 1.3991 & 5 \\
\hline
\end{tabular}

calcined at $500^{\circ} \mathrm{C}$ for $6 \mathrm{~h}$, on the other hand, displayed the rhombohedral polymorph of $\mathrm{Ga}_{2} \mathrm{O}_{3}$. This phase was identified by ICDD PDF 06-0503. The only phase identified in the XRD spectra of $750^{\circ}, 1000^{\circ}$, and $1200^{\circ} \mathrm{C}$ was the monoclinic polymorph of $\mathrm{Ga}_{2} \mathrm{O}_{3}$. This phase was identified by ICDD PDF 41-1103 and 76-0573. With an increase in the calcination temperature from $750^{\circ}$ to $1200^{\circ} \mathrm{C}$, the intensities of the XRD peaks have increased considerably.

Knowing that the commercially available $\mathrm{Ga}_{2} \mathrm{O}_{3}$ powders (e.g., Sigma-Aldrich) possess the monoclinic crystal structure, and that it is almost impossible to convert them to the rhombohedral polymorph by heating, for instance, at $500^{\circ} \mathrm{C}$ even for prolonged times, the synthesis method described here can also be regarded as a simple way of manufacturing the rhombohedral $\mathrm{Ga}_{2} \mathrm{O}_{3}$ powders of uniform morphology.
The results of the TG/DTA analyses of $\mathrm{GaO}(\mathrm{OH})$ crystals produced by using both kinds of synthesis procedures of this study are summarized in Fig. 5. It should be mentioned here that the DTA trace for the crystals produced in the presence of urea has been lowered by about $4 \mu \mathrm{V}$, during plotting, to avoid overlapping with the other DTA trace. All other traces are plotted as they were obtained.

Gallium oxide hydroxide produced by "forced hydrolysis" displayed a total weight loss of $13.01 \%$ (from $50^{\circ}$ to $110^{\circ} \mathrm{C}$, $0.38 \%$; from $110^{\circ}$ to $250^{\circ} \mathrm{C}, 1.26 \%$; from $250^{\circ}$ to $350^{\circ} \mathrm{C}, 2.47 \%$; from $350^{\circ}$ to $440^{\circ} \mathrm{C}, 8.86 \%$; and from $440^{\circ}$ to $700^{\circ} \mathrm{C}, 0.04 \%$ ), while the samples produced in the presence of urea showed a total weight loss of $13.38 \%$ (from $50^{\circ}$ to $110^{\circ} \mathrm{C}, 2.85 \%$; from $110^{\circ}$ to $250^{\circ} \mathrm{C}, 2.75 \%$; from $250^{\circ}$ to $350^{\circ} \mathrm{C}, 2.75 \%$; from $350^{\circ}$ to $440^{\circ} \mathrm{C}$, $4.50 \%$; and from $440^{\circ}$ to $700^{\circ} \mathrm{C}, 0.53 \%$ ). It can immediately be stated at this point that the formula of the freshly precipitated crystals was not simply $\mathrm{GaO}(\mathrm{OH})$. If they indeed were stoichiometric $\mathrm{GaO}(\mathrm{OH})$, then the total weight loss must have been in the vicinity of $8.8 \%$.

The TG/DTA traces also indicate a significant difference between the dehydration nature of "urea-" and "no-ureaprecipitated" crystals. The total dehydration of urea-precipitated samples took place in three differentiated steps (while the dehydration of samples produced by forced hydrolysis took place in two steps). In the first step (between $50^{\circ}$ and $110^{\circ} \mathrm{C}$ ), the elimination of physical, as well as surface adsorbed, water was achieved, which was also accompanied by an endothermic DTA peak. The urea-precipitated little zeppelins were therefore shown (by the TG analysis alone) to adsorb about 7 times more surface water $(2.85 \%$ weight loss in the first step) than rodlike crystals ( $0.41 \%$ weight loss). The second step of dehydration of the urea-precipitated samples was identified by a unique exothermic event (which was not observed at all in the forced-hydrolysis samples) at above $250^{\circ} \mathrm{C}$. This exothermic event may be attributed to the release of surface bound hydroxyl groups. The granular surface texture of the zeppelins of Figs. 2(a) and (b) was believed to result (after long electron beam exposure) from such dehydroxylation. The broad endothermic peaks (for both samples) appearing between $290^{\circ}$ and $400^{\circ} \mathrm{C}$ were due to the elimination of water from constitutional $\mathrm{OH}$ groups and conversion to $\mathrm{Ga}_{2} \mathrm{O}_{3}$. The exothermic event observed in both samples over the temperature range of

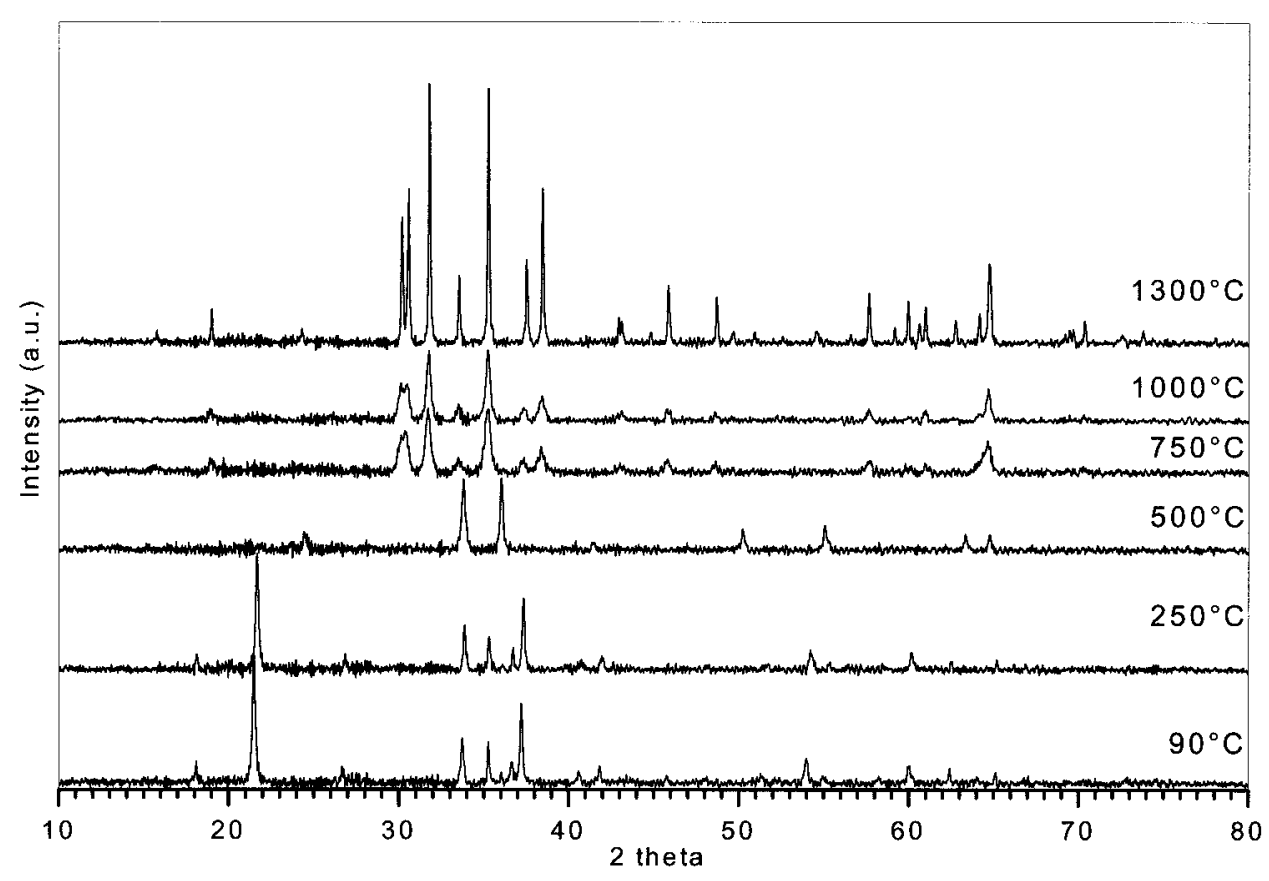

Fig. 4. XRD spectra of samples of this study as a function of temperature $\left(90^{\circ}\right.$ and $250^{\circ} \mathrm{C}$, orthorhombic $\alpha-\mathrm{GaOOH} \times x \mathrm{H}_{2} \mathrm{O} ; 500^{\circ} \mathrm{C}$, rhombohedral $\mathrm{Ga} \mathrm{O}_{3}$; $750^{\circ}, 1000^{\circ}$, and $1200^{\circ} \mathrm{C}$, monoclinic $\mathrm{Ga}_{2} \mathrm{O}_{3}$ ). 


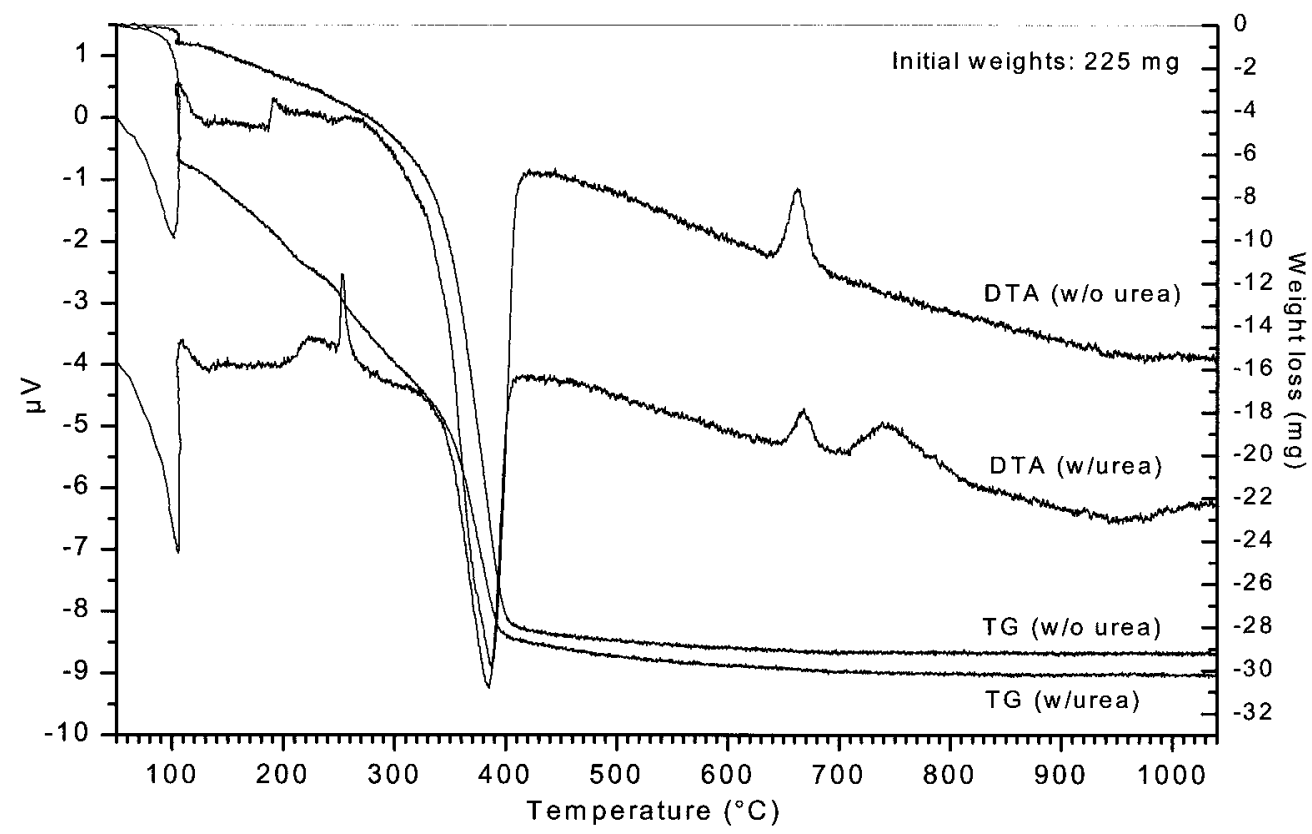

Fig. 5. Combined TG/DTA traces for $\mathrm{GaO}(\mathrm{OH})$ crystals produced in aqueous solutions with or without urea.

$635^{\circ}$ to $670^{\circ} \mathrm{C}$ was due to the crystallization of monoclinic $\beta-\mathrm{Ga}_{2} \mathrm{O}_{3}$. Apparently, for "urea-precipitated" powders the observation of a second exothermic shoulder at around $700^{\circ}$ to $780^{\circ} \mathrm{C}$ was due to the slower and stepwise nature of crystallization taking place in these samples.

For the $\mathrm{GaO}(\mathrm{OH})$ crystals prepared from either urea-containing solutions or pure water solutions, representative infrared spectra are given in Fig. 6. The spectra labeled 5 through 8 were observed to be exactly the same for both types of samples. (However, the IR traces given as 5 to 8 , in Fig. 6, are the spectra of forced-hydrolysis samples.) The IR spectra of $90^{\circ}$ - and $250^{\circ} \mathrm{C}$-heated samples (traces which are labeled 1 through 4 ) reveal a broad $\mathrm{H}-\mathrm{O}-\mathrm{H}$ stretching band at around $3400 \mathrm{~cm}^{-1}$ and an $\mathrm{OH}$ bending at $1630 \mathrm{~cm}^{-1}$. The bands at 2344 and $1384 \mathrm{~cm}^{-1}$ are due to adsorbed atmospheric $\mathrm{CO}_{2}$, which resulted from the preparation and processing of FTIR samples in the ambient atmosphere. On the other hand, the bands at 2036 and $1942 \mathrm{~cm}^{-1}$, together with the bands at 1026 and 952 $\mathrm{cm}^{-1}$, are assigned to constitutional $\mathrm{Ga}-\mathrm{OH}$ bending bands, and their overtones, respectively, in close agreement with Sato et al. ${ }^{26}$ The group of bands (including those at 690 and $645 \mathrm{~cm}^{-1}$ ) appearing within the range of $1200-600 \mathrm{~cm}^{-1}$ are characteristic $\mathrm{M}-\mathrm{OH}$ deformation bands seen in hydroxo complexes. ${ }^{68}$ With increasing calcination temperature, all IR bands attributed to anion vibrations disappear, and gallium oxide absorption bands start to be visible beginning with trace 5 (i.e., sample calcined at $500^{\circ} \mathrm{C}$ ) of Fig. 6. FTIR analysis showed that structural $\mathrm{CO}_{3}{ }^{2-}$ or $\mathrm{NO}_{3}{ }^{-}$

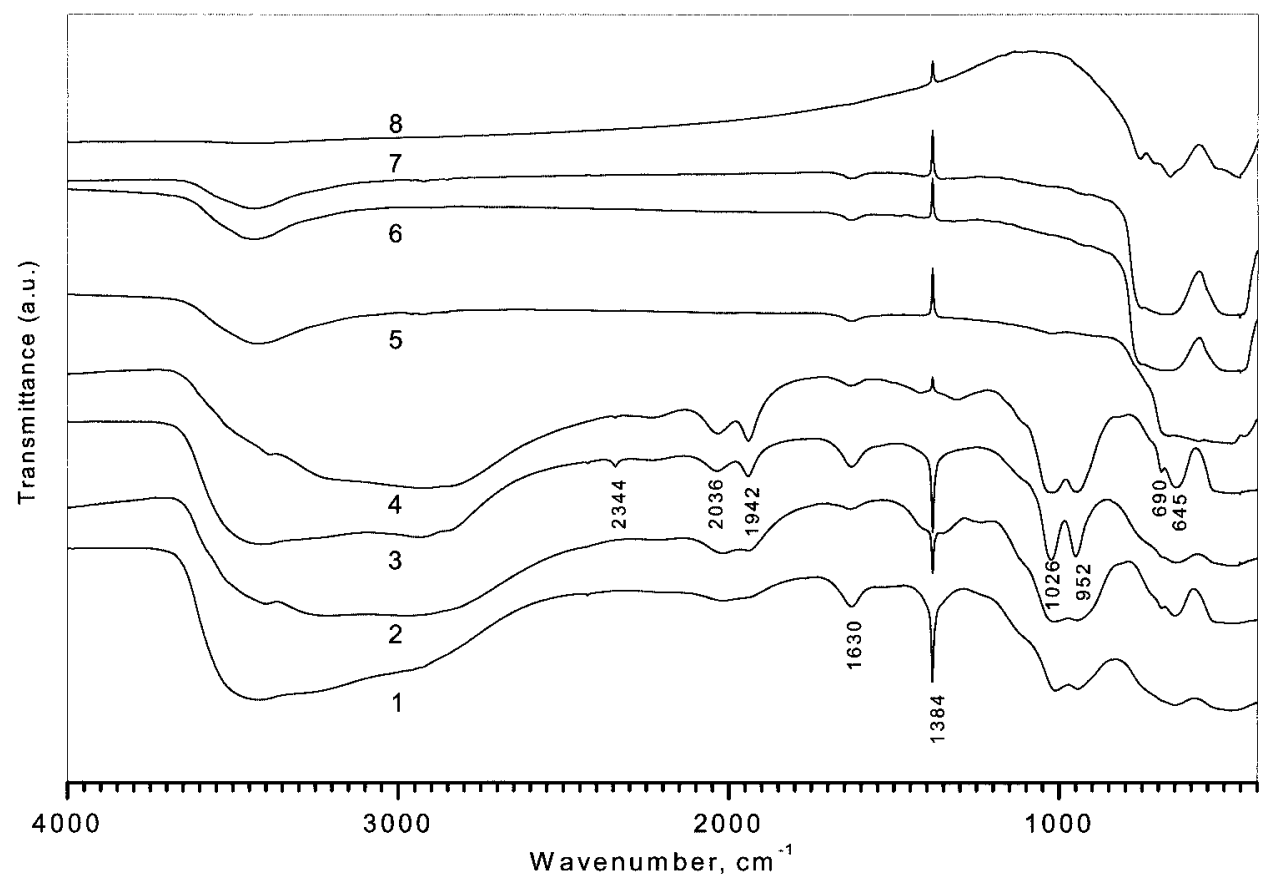

Fig. 6. FTIR spectra of gallium oxide hydroxide (initial) crystals as a function of calcination temperature: (1) $90^{\circ} \mathrm{C}$, with urea; (2) $90^{\circ} \mathrm{C}$, without urea; (3) $250^{\circ} \mathrm{C}$, with urea; (4) $250^{\circ} \mathrm{C}$, without urea; (5) $500^{\circ} \mathrm{C}$, without urea; $(6) 750^{\circ} \mathrm{C}$, without urea; (7) $1000^{\circ} \mathrm{C}$, without urea; (8) $1200^{\circ} \mathrm{C}$, without urea. 
ions were not present (as supported by the quantitative $\mathrm{C}$ and $\mathrm{N}$ analyses on those samples) in either type of crystal in this study.

Relying on the combined results of the TG/DTA, FTIR, and C and $\mathrm{N}$ analyses, the chemical formula of the rodlike crystals produced (after $90^{\circ} \mathrm{C}$ drying) by the method of forced hydrolysis was estimated to be $\mathrm{GaOOH} \cdot 0.25 \mathrm{H}_{2} \mathrm{O}$. On the other hand, the formula of the crystals obtained (following drying at $90^{\circ} \mathrm{C}$ ) by the technique of homogeneous decomposition of urea was determined to be $\mathrm{GaOOH} \cdot 0.112 \mathrm{H}_{2} \mathrm{O}$. The coefficients in front of the crystal waters in these formulas may vary on prolonged exposure of those to the ambient atmosphere.

\section{Conclusions}

The following conclusions can be made from the results presented:

(1) On heating a dilute $(0.026 \mathrm{M})$ aqueous solution of gallium nitrate at about $90^{\circ} \mathrm{C}$ for $95 \mathrm{~min}$ (i.e., forced hydrolysis), rodlike, monodispersed, 1 to $3 \mu \mathrm{m}$ long orthorhombic $\mathrm{GaOOH} \cdot x \mathrm{H}_{2} \mathrm{O}$ single crystals can be formed (starting at a $\mathrm{pH}$ value of 2.05 at $85^{\circ} \mathrm{C}$ ), where the value of $x$ is in the vicinity of 0.25 .

(2) On heating a dilute $(0.026 \mathrm{M})$ aqueous solution of gallium nitrate, which also contains $0.304 M$ urea (i.e., homogeneous decomposition of urea), to about $85^{\circ} \mathrm{C}$, zeppelin-shaped, monodispersed, 200-500 nm long, orthorhombic $\mathrm{GaOOH} \cdot \mathrm{H}_{2} \mathrm{O}$ single crystals can be formed, again at the exact $\mathrm{pH}$ value of 2.05 . The value of $x$ in the formula is $\sim 0.11$.

(3) Both types of gallium oxide hydroxide single crystals transform first into rhombohedral and then into monoclinic polymorphs of $\mathrm{Ga}_{2} \mathrm{O}_{3}$, on calcination in an air atmosphere for $6 \mathrm{~h}$ at temperatures $\geq 500^{\circ} \mathrm{C}$

(4) The initial zeppelin-like morphology (which is also observed for $\alpha-\mathrm{FeOOH}$ by previous researchers) of crystals, formed in solutions containing urea, starts slowly disappearing (changing into a nodular one) on calcination at temperatures $\geq 750^{\circ} \mathrm{C}$, but the rodlike morphology of crystals formed by forced hydrolysis persists even after calcination at $1200^{\circ} \mathrm{C}$. The rodlike crystals of $\mathrm{GaOOH} \cdot x \mathrm{H}_{2} \mathrm{O}$ become nanoporous on their visible surfaces with an increase in calcination temperature.

(5) Carbon and nitrogen analyses, as well as the FTIR results, show that the formed crystals (following drying at $90^{\circ} \mathrm{C}$ ) do not contain any structural $\mathrm{CO}_{3}{ }^{2-}$ and $\mathrm{NO}_{3}{ }^{-}$ions.

\section{Acknowledgments}

One of the authors, Dr. A. C. Taş, gratefully acknowledges the Max-PlanckInstitute fuer Metallforschung, Stuttgart, for the award of a Visiting Professorship, extending over the term of February 1999 to February 2001. The authors also express their gratitude to M. Thomas (XRD), H. Labitzke (FESEM), F. Predel (SEM), H Kummer (TG/DTA), W. Konig (FT-IR), G. Kaiser (ICP-AES), and S. Hammoud (C and $\mathrm{N}$ analyses) for their generous help with sample characterization.

\section{References}

${ }^{1}$ R. C. Weast, D. R. Lide, M. J. Astle, and W. H. Beyer (eds.), CRC Handbook of Chemistry and Physics, 70th Ed.; p. B-17. CRC Press, Boca Raton, FL, 1990.

${ }^{2}$ C. Klein and C. S. Hurlbut, Manual of Mineralogy; pp. 222-23. Wiley, New York, 1993.

${ }^{3}$ L. Binet, D. Gourier, and C. Minot, "Relation between Electron Band Structure and Magnetic Bistability of Conduction Electrons in $\beta_{-} \mathrm{Ga}_{2} \mathrm{O}_{3}$," J. Solid State Chem. 113, 420-33 (1994)

${ }^{4} \mathrm{~L}$. Binet and D. Gourier, "Origin of the Blue Luminescence of $\beta-\mathrm{Ga}_{2} \mathrm{O}_{3}$," J. Phys. Chem. Solids, 59, 1241-49 (1998).

${ }^{5}$ S. Geller, "Crystal Structure of $\beta-\mathrm{Ga}_{2} \mathrm{O}_{3}$," J. Chem. Phys., 33, 676-84 (1960).

${ }^{6} \mathrm{~J}$. Ahman, G. Svensson, and J. Albertsson, "A Reinvestigation of $\beta$-Gallium Oxide," Acta Crystallogr., C52, 1336-38 (1996).

${ }^{7}$ A. W. Laubengayer and H. R. Engle, "The Sesquioxide and Hydroxide of Gallium," J. Am. Chem. Soc., 61, 1210-14 (1939).

${ }^{8}$ R. Roy, V. G. Hill, and E. F. Osborn, "Polymorphism of $\mathrm{Ga}_{2} \mathrm{O}_{3}$ and the System of $\mathrm{Ga}_{2} \mathrm{O}_{3}-\mathrm{H}_{2} \mathrm{O}$," J. Am. Chem. Soc., 74, 719-22 (1952).

${ }^{9}$ I. A. Bashmakov, Y. V. Kalinichenko, V. V. Platon, M. Y. Rakhlin, and V. E. Rodionov, "Structure and Composition of Gallium Oxide," Inorg. Mater., 28, 419-22 (1992)

${ }^{10} \mathrm{M}$. Fleischer, L. Höllbauer, E. Born, and H. Meixner, "Evidence for a Phase Transition of $\beta$-Gallium Oxide at Very Low Oxygen Pressures," J. Am. Ceram. Soc., 80, 2121-25 (1997)
${ }^{11}$ T. Hartwig, G. J. Wubs, and G. J. Dirksen, "Electrical Properties of $\beta-\mathrm{Ga}_{2} \mathrm{O}_{3}$ Single Crystals," Solid State Commun., 18, 223-25 (1976).

${ }^{12} \mathrm{~S}$. Okada, K. Kudou, and I. Higashi, "Growth of $\beta-\mathrm{Ga}_{2} \mathrm{O}_{3}$ Single Crystals by the Tin-Flux Method," Nippon Kagaku Kaishi, 10, 1426-31 (1991).

${ }^{13}$ H. Z. Zhang, Y. C. Kong, Y. Z. Wang, X. Du, Z. G. Bai, J. J. Wang, Y. Ding, D. P. Yu, Q. L. Hang, and S. Q. Feng, " $\mathrm{Ga}_{2} \mathrm{O}_{3}$ Nanowires Prepared by Physical Evaporation," Solid State Commun., 109, 677-82 (1999).

${ }^{14}$ Y. C. Choi, W. S. Kim, Y. S. Park, S. M. Lee, D. J. Bae, Y. H. Lee, G. S. Park, W. B. Choi, N. S. Lee, and J. M. Kim, "Catalytic Growth of $\beta-\mathrm{Ga}_{2} \mathrm{O}_{3}$ Nanowires by Arc Discharge," Adv. Mater., 12, 746 (2000).

${ }^{15} \mathrm{M}$. Fleischer and H. Meixner, "Sensing Reducing Gases at High Temperatures using Long-Term Stable $\mathrm{Ga}_{2} \mathrm{O}_{3}$ Thin Films," Sens. Actuators, B6, 277-81 (1992).

${ }^{16}$ M. Fleischer and H. Meixner, "Oxygen Sensing with Long-Term Stable $\mathrm{Ga}_{2} \mathrm{O}_{3}$ Thin Films," Sens. Actuators, B5, 115-19 (1992).

${ }^{17} \mathrm{M}$. Fleischer and H. Meixner, "A Selective $\mathrm{CH}_{4}$ Sensor Using Semiconducting $\mathrm{Ga}_{2} \mathrm{O}_{3}$ Thin Films Based on Temperature Switching of Multigas Reactions," Sens. Actuators, B24-25, 544-47 (1995).

${ }^{18}$ J. Frank, M. Fleischer, and H. Meixner, "Electrical Doping of Gas-Sensitive, Semiconducting $\mathrm{Ga}_{2} \mathrm{O}_{3}$ Thin Films," Sens. Actuators, B34, 373-77 (1996).

${ }^{19}$ J. Frank, M. Fleischer, and H. Meixner, "Gas-Sensitive Electrical Properties of Pure and Doped Semiconducting $\mathrm{Ga}_{2} \mathrm{O}_{3}$ Thick Films," Sens. Actuators, B48, 318-21 (1998).

${ }^{20} \mathrm{M}$. Haneda, Y. Kintaichi, H. Shimada, and H. Hamada, " $\mathrm{Ga}_{2} \mathrm{O}_{3} / \mathrm{Al}_{2} \mathrm{O}_{3}$ Prepared by Sol-Gel Method as a Highly Active Metal Oxide-Based Catalyst for NO Reduction by Propene in the Presence of Oxygen, $\mathrm{H}_{2} \mathrm{O}$, and $\mathrm{SO}_{2}$," Chem. Lett., [2] 181-82 (1998).

${ }^{21}$ M. Haneda, Y. Kintaichi, H. Shimada, and H. Hamada, "Selective Reduction of $\mathrm{NO}$ with Propene over $\mathrm{Ga}_{2} \mathrm{O}_{3}-\mathrm{Al}_{2} \mathrm{O}_{3}$ : Effect of Sol-Gel Method on the Catalytic Performance," J. Catal., 192, 137-48 (2000).

${ }^{22} \mathrm{~T}$. Ishihara, H. Matsuda, and Y. Takita, "Doped $\mathrm{LaGaO}_{3}$ Perovskite Type Oxide as a New Oxide Ionic Conductor," J. Am. Chem. Soc., 116, 3801-803 (1994).

${ }^{23}$ M. Feng and J. B. Goodenough, "A Superior Oxide-Ion Electrolyte," Eur. J. Solid State Inorg. Chem., T31, 663-72 (1994).

${ }^{24}$ A. C. Taş, P. J. Majewski, and F. Aldinger, "Chemical Preparation of Pure and Strontium- and/or Magnesium-Doped Lanthanum Gallate Powders," J. Am. Ceram. Soc., 83, 2954-60 (2000).

${ }^{25}$ A. C. Taş, P. Majewski, and F. Aldinger, "Preparation of Strontium- and Zinc-Doped $\mathrm{LaGaO}_{3}$ Powders via Precipitation in the Presence of Urea and/or Enzyme Urease," J. Am. Ceram. Soc., 85 [6] 1414-20 (2002).

${ }^{26} \mathrm{~T}$. Sato and T. Nakamura, "Studies of the Crystallisation of Gallium Hydroxide Precipitated from Hydrochloric Acid Solutions by Various Alkalis," J. Chem. Tech. Biotechnol., 32, 469-75 (1982).

${ }^{27}$ R. J. Hill, "Crystal Structure Refinement and Electron Density Distribution in Diaspore," Phys. Chem. Miner., 5, 179-200 (1979).

${ }^{28}$ A. Klug and L. Farkas, "Structural Investigations of Polycrystalline Diaspore Samples by X-ray Powder Diffraction," Phys. Chem. Miner., 7, 138-40 (1981).

${ }^{29}$ G. S. Pokrovski, I. I. Diakonov, P. Benezeth, V. M. Gurevich, K. S. Gavrichev, V. E. Gorbunov, J.-L. Dandurand, J. Schott, and I. L. Khodakovsky, "Thermodynamic Properties of Gallium Hydroxide Oxide $(\alpha-\mathrm{GaOOH})$ at Temperatures to $700 \mathrm{~K}$," Eur. J. Mineral., 9, 941-51 (1997).

${ }^{30}$ A. N. Christensen and S. J. Jensen, "Hydrothermal Preparation of $\alpha-\mathrm{ScOOH}$ and of $\gamma$-ScOOH," Acta Chem. Scand., 21, 121-26 (1967).

${ }^{31}$ L. S. D. Glasser and L. Ingram, "Refinement of the Crystal Structure of Groutite, - $-\mathrm{MnOOH,"} \mathrm{Acta} \mathrm{Crystallogr.,} \mathrm{B24,} \mathrm{1233-36} \mathrm{(1968).}$

${ }^{32}$ J. Lima-de-Faria, "Anomalous Orientations of Cubic Close Packing in the Dehydration of Goethite in an Inert Atmosphere," Acta Crystallogr., 23, 733-36 (1967).

${ }^{33}$ J. B. Forsyth, I. G. Hedley, and C. E. Johnson, "The Magnetic Structure and Hyperfine Field of Goethite ( $\alpha$-FeOOH)," J. Phys. C, 1, 179-88 (1968).

${ }^{4}$ C. F. Sampson, "The Lattice Parameters of Natural Single Crystal and Synthetically Produced Goethite ( $\alpha$-FeOOH)," Acta Crystallogr., B25, 1683-85 (1969).

${ }^{35}$ K. Parida and J. Das, "Studies on Ferric Oxide Hydroxides. 2. Structural Properties of Goethite $(\alpha-\mathrm{FeOOH})$ Prepared by Homogeneous Precipitation from $\mathrm{Fe}\left(\mathrm{NO}_{3}\right)_{3}$ Solution in the Presence of Sulfate Ions," J. Colloid Interface Sci., 178, 586-93 (1996)

${ }^{36}$ S. Avivi, Y. Mastai, G. Hodes, and A. Gedanken, "Sonochemical Hydrolysis of $\mathrm{Ga}^{3+}$ Ions: Synthesis of Scroll-like Cylindrical Nanoparticles of Gallium Oxide Hydroxide," J. Am. Chem. Soc., 121, 4196-99 (1999).

${ }^{37}$ S. Avivi, Y. Mastai, and A. Gedanken, "Sonohydrolysis of $\mathrm{In}^{3+}$ Ions: Formation of Needlelike Particles of Indium Hydroxide," Chem. Mater. 12, 1229-33 (2000).

${ }^{38}$ K. Yura, K. C. Fredrikson, and E. Matijevic, "Preparation and Properties of Uniform Colloidal Indium Compounds of Different Morphologies," Colloids Surf., 50, 281-93 (1990)

${ }^{39}$ K. Fujita, K. Matsuda, and I. Kayama, "Study of Hydrated Alumina Gel through Homogeneous Precipitation Method," Nippon Kagaku Kaishi, 8, 1421-24 (1974).

${ }^{40}$ C. J. Serna, J. L. White, and S. L. Hem, "Factors Affecting Homogeneous Precipitation of Aluminum Hydroxide Gel," J. Pharm. Sci., 67, 1179-81 (1978).

${ }^{41}$ B. C. Cornilsen and J. E. Reed, "Homogeneous Precipitation of Basic Aluminum Salts as Precursors for Alumina," Am. Ceram. Soc. Bull., 58, 1999 (1979).

${ }^{42}$ E. Matijevic, "Monodispersed Colloids-Art and Science," Langmuir, 2, 12-20 (1986).

${ }^{43}$ A. Celikkaya and M. Akinc, "Preparation and Mechanism of Formation of Spherical Submicrometer Zinc Sulfide Powders," J. Am. Ceram. Soc., 73, 2360-65 (1990).

${ }^{44}$ Z. C. Kang, T. Z. Li, and L. Eyring, "The Preparation and Characterization of Hydroxycarbonate Colloidal Particles of Individual and Mixed Rare Earth Elements," J. Alloys Compd., 181, 477-82 (1992).

${ }^{45}$ E Matijevic, "Preparation and Properties of Uniform Size Colloids," Chem. Mater., 5, 412-26 (1993) 
${ }^{46} \mathrm{P}$. L. Chen and I-W. Chen, "Reactive Cerium(IV) Oxide Powders by the Homogeneous Precipitation Method," J. Am. Ceram. Soc., 76, 1577-83 (1993).

${ }^{47}$ D. J. Sordelet, M. Akinc, M. L. Panchula, Y. Han, and M. H. Han, "Synthesis of Yttrium-Aluminum-Garnet Precursor Powders by Homogeneous Precipitation," J. Eur. Ceram. Soc., 14, 123-30 (1994).

${ }^{48}$ I. Jaymes, A. Douy, D Massiot, and J. P. Busnel, "Synthesis of a Mulite Precursor from Aluminum Nitrate and Tetraethoxysilane via Aqueous Homogeneous Precipitation: An Al-27 and Si-29 Liquid-State and Solid-State NMR Spectroscopic Study," J. Am. Ceram. Soc., 78, 2648-54 (1995).

${ }^{49}$ L. F. Wang, I. Sondi, and E. Matijevic, "Preparation of Uniform Needle-like Aragonite Particles by Homogeneous Precipitation," J. Colloid Interface Sci., 218 , 545-53 (1999)

${ }^{50}$ A. C. Taş, "Preparation of Lead Zirconate Titanate $\left(\mathrm{Pb}\left(\mathrm{Zr}_{0.52} \mathrm{Ti}_{0.48}\right) \mathrm{O}_{3}\right)$ by Homogeneous Precipitation and Calcination," J. Am. Ceram. Soc., 82, 1582-84 (1999).

${ }^{51}$ L. A. Perez-Maqueda, L. Wang, and E. Matijevic, "Nanosize Indium Hydroxide by Peptization of Colloidal Precipitates," Langmuir, 14, 4397-401 (1998).

${ }^{52}$ A. Kato and Y. Morimitsu, "Formation of Iron(III) Hydroxide Particles from Iron(III) Salt Solutions by Homogeneous Precipitation Method," Nippon Kagaku Kaishi, 6, 800-807 (1984).

${ }^{53}$ S. Goni-Elizalde and M. E. Garcia-Clavel, "Characterization of Goethite Samples of Varying Crystallinity Obtained by the Homogeneous Precipitation Method," J. Am Ceram. Soc., 73, 121-26 (1990).

${ }^{54}$ M. Dixit, G. N. Subbanna, and P. V. Kamath, "Homogeneous Precipitation from Solution by Urea Hydrolysis: A Novel Chem. Route to the Alpha-Hydroxides of Nickel and Cobalt," J. Mater. Chem., 6, 1429-32 (1996).

${ }^{55}$ D. E. Appleman and H. T. Evans, "Indexing and Least-Squares Refinement of Powder Diffraction Data," U.S. Geol. Surv., GD-73-003 (1973).

${ }^{56}$ W. H. R. Shaw and J. J. Bordeaux, "The Decomposition of Urea in Aqueous Media," J. Am. Chem. Soc., 77, 4729-33 (1955).
${ }^{57}$ S. Ramanathan, S. K. Roy, R. Bhat, D. D. Upadhyaya, and A. R. Biswas, "Alumina Powders from Aluminum Nitrate-Urea and Aluminum Sulphate-Urea Reactions: The Role of the Precursor Anion and Process Conditions on Characteristics," Ceram. Int., 23, 45-53 (1997).

${ }^{58}$ R. C. MacKenzie and R. Meldau, "The Aging of Sesquioxide Gels, (I) Iron Oxide Gels," Miner. Mag. J. Mineral. Soc., 32, 153 (1959).

${ }^{59} \mathrm{G}$. W. Van Oosterhout, "The Transformation of $\gamma-\mathrm{FeO}(\mathrm{OH})$ to $\alpha-\mathrm{FeO}(\mathrm{OH})$," J. Inorg. Nucl. Chem., 29, 1235-38 (1967).

${ }^{60}$ S. Goni-Elizalde and M. E. Garcia-Clavel, "Thermal Behaviour in Air of Iron Oxyhydroxides Obtained from the Method of Homogeneous Precipitation, Part II. Akaganeite Sample," Thermochim. Acta, 129, 325-34 (1988).

${ }^{61}$ R. M. Cornell and R. Giovanoli, "Effect of Solution Conditions on the Proportion and Morphology of Goethite Formed from Ferrihydrite," Clays Clay Miner., 33, 424-32 (1985)

${ }^{62}$ C.-H. Lu and C.-H. Yeh, "Influence of Hydrothermal Conditions on the Morphology and Particle Size of Zinc Oxide Powder," Ceram. Int., 26, 351-57 (2000).

${ }^{63} \mathrm{H}$. Kurokawa, "Geometrical Characterization of Acicular Goethite Particles in Systematically Controlled Processing," Mater. Sci. Eng., A202, 201-205 (1995).

${ }^{64}$ T. Wang, Y. Jin, Z. Wang, and Z. Yu, "A Study of the Morphology of the Goethite Crystallization Process," Chem. Eng. J., 69, 1-5 (1998).

${ }^{65}$ G. Wang, G. Whittaker, A. Harrison, and L. Song, "Preparation and Mechanism of Formation of Acicular Goethite-Magnetite Particles by Decomposition of Ferric and Ferrous Salts in Aqueous Solution using Microwave Radiation," Mater. Res. Bull., 33 [11] 1571-79 (1998).

${ }^{66}$ T. Ishikawa, Y. Kondo, A. Yasukawa, and K. Kandori, "Formation of Magnetite in the Presence of Ferric Oxyhydroxides," Corrosion Sci., 40 [7] 1239-51 (1998).

${ }^{67} \mathrm{H}$. Kurokawa and M. Senna, "Self-Stabilization of Green Rust (II) as a Precursor of Acicular Goethite Particles with Highest Possible Aspect Ratio," Powder Technol., 103, 71-79 (1999).

${ }^{68}$ G. Socrates, Infrared Characteristic Group Frequencies; p. 224. Wiley, New York, 1994. 